\title{
A Study on the Construction of Vocational and Commercial Professional Integration Practice Teaching System Based on Innovation and Start-up Ability
}

\author{
Lianming Zhao
}

Department of Business Management, Chongqing Business Vocational College, 401331, Chongqing, China

Keywords: Innovation and entrepreneurship; Ability; Higher vocational education. Major in business and trade;

\begin{abstract}
Entrepreneurial ability is listed by UNESCO as the third ability of college students after academic and vocational skills. How to launch a startup education has become a new subject for education. Education is the best way to tap students' potential to develop students' basic qualities and cultivate students' comprehensive ability. Entrepreneurship education is the main stream of the development of higher education in the world, the worldwide education idea, has been around the world, including China, universal attention and recognition, and the core content of entrepreneurship education is to cultivate college students' career ability. The rapid development of higher vocational education in our country today, to discuss how to better cultivate students entrepreneurial ability, encourage the students take the path of self-employment, for higher vocational talents training research is of great significance.
\end{abstract}

\section{Introduction}

Since the reform and opening up, China's commercial service industry has been developing greatly and has made important contribution to national economic development. As a pillar industry in the tertiary industry, the commercial service industry has the characteristics of low starting point and quick benefit, which is suitable for college students to start their own business. A targeted training related professional students entrepreneurial ability, train and bring up practitioners, with entrepreneurial spirit and entrepreneurial ability can optimize allocation of human resources, and promote industrial development and enhance the vitality of the national economy. The commercial service industry is an extremely active source of economic growth, which can absorb surplus labor effectively. At the same time, trade and business service industry is a high added value, low emissions, the development potential of the industry, entrepreneurial talent cultivated a batch of high-quality business services, for the healthy development of the regional industry, the transformation and upgrading has important practical value.

In 2015, the state council officially issued by the general office of the state council on deepening the reform of institutions of higher learning innovation entrepreneurship education of the implementation opinions ", for universities in the process of teaching for college students, should pay attention to the cultivation of the innovation ability of students. As the main position of education, higher vocational colleges have the responsibility to cultivate application-oriented talents with innovative awareness and entrepreneurial ability. In recent years, various vocational colleges have actively explored the realization path of innovation and entrepreneurial ability of college students, and have done a great deal of beneficial exploration in the innovative talent cultivation mode. Innovation refers to the improvement or creation of new methods, elements, paths, and environment in a given situation with existing knowledge and material. The so-called innovation ability mainly refers to the ability to innovate, innovative and innovative thinking and transform it into innovative results in actual work. Entrepreneurship is through their own efforts to have the resources or to have the resources to optimize configuration and integration, start and run a business independently and create greater social and economic value. Entrepreneurship refers to have find or create a new field, we are committed to creating new things to understand ability, be able to use various methods to use 
and develop them, and then produce a variety of new results. The cultivation of college students' entrepreneurial ability is mainly refers to through the entrepreneurship education of college students have to adapt to the social survival and self development ability, improve professional quality and consciousness of the individual, to master the methods and skills to start a business independently, and enhance their competitiveness. The teaching content system of practice is mainly composed of the various practical teaching links. Vocational and trade majors should be guided by the training of foreign trade compound technical skills with innovative consciousness and entrepreneurial skills, and the main line of practical teaching content will be integrated into innovation and entrepreneurship teaching

\section{Innovative ability to cultivate the status quo}

Because China is still in the primary stage of socialist development, there is still a certain gap between economic development and social development compared with developed countries. Innovation and entrepreneurship education initial formation, education level needs to be improved, the quality of intellectual property needs to be improved. There is more emotion and experience than experiment. These are the factors that restrict the development of education in the management of private colleges and universities. Part in the creative education, private colleges teaching management major innovation entrepreneurship education and the professional advantages of existing resources consolidation, but should avoid as far as possible to achieve a certain effect is stagnant, not further exploration and deepening the research. In the process of innovation and entrepreneurship education implementation, there are some controversies about the appraisal and evaluation of education results. Most privately-run colleges and universities have identified the innovation and entrepreneurship works of college students as innovation and entrepreneurship, which are not comprehensive enough. Teachers pay attention to knowledge transfer in the way of books, classes and lectures, but ignore the training of students' practical skills, and the way of situational teaching is less adopted. The autonomy of students lack of innovation, only know what to do, but, think about why do change how to deal with, resulting in some students entrepreneurial practice, a strain capacity is not high. The interconnections between schools and businesses need to be improved. Because innovation and entrepreneurship education results are more flexible and delayed, it also makes it more difficult to evaluate professional education.

$$
T=\left[\begin{array}{cccc}
a_{11} & a_{12} & \cdots & a_{1 n} \\
a_{21} & a_{22} & \cdots & a_{2 n} \\
\cdots & \cdots & \cdots & \cdots \\
a_{m 1} & a_{m 2} & \cdots & a_{m n}
\end{array}\right]
$$

At present, there are still part of creative education in colleges and universities lack enough understanding, not from the height of the construction of an innovative country and cultivating innovative talents to recognize the importance of creative education, more don't realize innovative entrepreneurship education and realize the goal of talent cultivation and the relationship between the students entrepreneurial employment competitiveness, attaches great importance to the professional class education, only don't pay much attention to the students' innovative undertaking education. Many colleges and universities of college students' innovative undertaking education work tend to be "three minutes enthusiasm", the corresponding new entrepreneurship become a mere formality, inadequate investment on capital, manpower and material resources, the concrete work not implement, do not reach the designated position, not to establish a system innovation entrepreneurship education system, especially the lack of practice teaching method and practice base, practice ability weak become the key factor restricting college students' innovative undertaking. 


$$
\left[\begin{array}{llll}
x^{*} & y^{*} & z^{*} & 1
\end{array}\right]=\left[\begin{array}{llll}
x & y & z & 1
\end{array}\right]\left[\begin{array}{rrrr}
1 & 0 & 0 & 0 \\
0 & 1 & 0 & 0 \\
0 & 0 & 1 & 0 \\
T_{X} & T_{Y} & T_{Z} & 1
\end{array}\right]=\left[\begin{array}{llll}
x+T_{x} & y+T_{y} & z+T_{z} & 1
\end{array}\right]
$$

Rotate around the $\mathrm{X}$ axis:

$$
\left[\begin{array}{llll}
x^{*} & y^{*} & z^{*} & 1
\end{array}\right]=\left[\begin{array}{llll}
x & y & z & 1
\end{array}\right]\left[\begin{array}{cccc}
1 & 0 & 0 & 0 \\
0 & \cos \theta & \sin \theta & 0 \\
0 & -\sin \theta & \cos \theta & 0 \\
0 & 0 & 0 & 1
\end{array}\right]
$$

Rotate around the $\mathrm{Y}$ axis:

$$
\left[\begin{array}{llll}
x^{*} & y^{*} & z^{*} & 1
\end{array}\right]=\left[\begin{array}{llll}
x & y & z & 1
\end{array}\right]\left[\begin{array}{cccc}
\cos \theta & 0 & -\sin \theta & 0 \\
0 & 1 & 0 & 0 \\
\sin \theta & 0 & \cos \theta & 0 \\
0 & 0 & 0 & 1
\end{array}\right]
$$

Rotate around the $\mathrm{Z}$ axis:

$$
\left[\begin{array}{llll}
x^{*} & y^{*} & z^{*} & 1
\end{array}\right]=\left[\begin{array}{llll}
x & y & z & 1
\end{array}\right]\left[\begin{array}{cccc}
\cos \theta & \sin \theta & 0 & 0 \\
-\sin \theta & \cos \theta & 0 & 0 \\
0 & 0 & 1 & 0 \\
0 & 0 & 0 & 1
\end{array}\right]
$$

According to the survey, the rate of entrepreneurship of higher vocational students is up to $1.9 \%$, but the proportion of students majoring in economy and trade is relatively low. From the background of professional knowledge, business and trade service majors are entrepreneurial and even should be aware of this, but it is not the case. The main reason is the problem of education orientation and teaching method. In the long run, the school in the aspect of entrepreneurship education in teachers, the size of the set of classes, each class are still very limited, must want to change the status quo, to cultivate the students' ability to become an important work in professional education, to break the traditional teaching concept and mode, build the second class and third class, the reform of practice teaching mode, to ensure the quality of teaching, make students have a more broad space for the students, giving full play to the advantages of personalized, in professional personnel training in the path of "double-track" education and entrepreneurial talent employment type talent cultivation at the same time, the mass education and elite education coexist.

\section{Innovative ability training mode}

Thoroughly updated up employment concept, in order to cultivate entrepreneurial talents for the purpose, change the traditional discipline theory teaching system, the change in the classroom as the center to take the market as the center, as a result, students in the process of practice, not only to let them learn technology, process, more important is to cultivate the students' pioneering consciousness, moral, enhance their awareness of the importance of student work, not afraid of hardships, should attach great importance to the learning of each practice teaching content, lay a foundation for future employment entrepreneurship.

To reform the current teaching mode, the innovation entrepreneurship as a compulsory course for the various professional literacy and skills of teaching, teaching with innovative entrepreneurial success, let students understand the entrepreneurial innovation, knowledge innovation entrepreneurship method and process, cultivate creative consciousness, inspire students' innovative entrepreneurial ideas, broaden the students entrepreneurial vision, insight and coordinated ability, the college students and the market strain capacity and entrepreneurial skills, to master the whole process of business model innovation development skills and strategies. 
The curriculum is the basic carrier of innovation and entrepreneurship education in vocational colleges. Guangdong vocational college of technology, majoring in creative education, higher vocational business schools existing conditions and professional characteristics, based on innovation, according to the talents training goal of cultivating high-quality technical skilled foreign trade orientation and creative ability training requirements, in order to realize the business professional knowledge education and innovation education organic fusion as direction, to the cultivation of the innovation business idea into the design of the curriculum system, innovative business ideas, entrepreneurial theory and knowledge, entrepreneurial practice three modules to construct based on creative ability training of specialized courses for higher vocational business system. Aiming at freshman freshmen in college, we have opened education courses of general education innovation and entrepreneurship, focusing on the creation of innovative entrepreneurial consciousness. Aiming at the students of second year of university, offering courses for entrepreneurship and providing theoretical support for the development of entrepreneurial practice; Aiming at students in the third grade of university, starting a curriculum of entrepreneurship practice focuses on cultivating students' entrepreneurial skills and helping them realize their dream of starting a business. At the same time, students are allowed to take innovative entrepreneurship courses across disciplines and levels.

\section{Summary}

To cultivate students' autonomous ability and entrepreneurial ability, develop the students' ability of practical application, in addition to strengthen the campus practice teaching, also should strengthen the students practice in business services companies. Especially some better large enterprises, the management of their corporate culture, the spirit of enterprise, the enterprise quality consciousness, competition consciousness, team spirit directly influence the improvement of students' vocational quality, entrepreneurial ability. Therefore, schools should make full use of social resources, extensive contacts with the enterprise, through a variety of partnerships set up a batch of adapted to local commerce service industry structure of off-campus practice base, use a variety of beneficial mechanism, and expand the scale of the practice base. Cultivating students' entrepreneurial consciousness, innovative spirit and innovative entrepreneurial ability is the goal of the reform and exploration of the practice teaching of private colleges and universities, which is an important means to alleviate the current employment contradiction. Build based on double of cultivating the ability of a private colleges management class specialized practice teaching system, training of professional talents in order to promote private colleges management mechanism transformation, trying to explore new approach of cultivating professional talents of higher management class.

\section{Acknowledgements}

This paper is supported by the 2017 Major Funded Project of Educational Sciences of Chongqing during the 13th Five-Year Plan Period. (Project Name: Research on the Construction of Integrated Practical Teaching system for Commercial and Trade Specialty in higher Vocational Colleges based on the cultivation of Innovative and Entrepreneurial ability. Project No. 2017-GX -049. ) This paper is the research result of the 2017 Educational Reform Research Project of Chongqing Business Vocational College. (Project Name: The Research and Practice on the '333' practical teaching system of Logistics Management specialty in higher Vocational Colleges based on the cultivation of Innovative and Entrepreneurial ability. Project No. SWJWJG201709.)

\section{References}

[1] The construction of education practice teaching system of university innovation and entrepreneurship in China [J]. Journal of education administration college, liaoning, 2015 (2): 65-72. (In Chinese)

[2] Chen hongwei. Research on the development of education and practice ability of college students' 
innovation and entrepreneurship [J]. Chinese business theory, 2016 (1): 33-36. (In Chinese)

[3] Chen jiang. Construction of education practice teaching system in higher vocational colleges [J]. Journal of zhejiang vocational and technical college of technology, 2014 (6): 59-62. (In Chinese)

[4] Niu li, Yin fan. The practice of innovation and entrepreneurial talent cultivation in deep integration of school enterprises [J]. Occupational technology education, 2014 (8): 49-52. (In Chinese)

[5] Zhou xiaoyong. Research on the teaching system of market marketing in the perspective of innovation and entrepreneurial ability training [J]. Education observation, 2015 (25): 19-23. (In Chinese).

[6] Liu jun. "innovation and entrepreneurship" education's connotation, problems and reform path analysis [J]. High education journal, 2016 (10): 31-32. (In Chinese). 